\title{
Sphingosine 1-Phosphate Receptors: Do They Have a Therapeutic Potential in Cardiac Fibrosis?
}

\author{
Ambra Vestri ${ }^{1+}$, Federica Pierucci ${ }^{1,2+}$, Alessia Frati ${ }^{1}$, Lucia Monaco ${ }^{3}$ and \\ Elisabetta Meacci ${ }^{1,2 *}$
}

1 Department of Experimental and Clinical Biomedical Sciences "Mario Serio", Molecular and Applied Biology Research Unit, University of Florence, Florence, Italy, ${ }^{2}$ Interuniversity Institutes of Myology, Firenze, Italy, ${ }^{3}$ Department of Physiology and Pharmacology "Vittorio Erspamer", Sapienza University of Rome, Rome, Italy

OPEN ACCESS

Edited by:

Chrishan S. Samuel,

Monash University, Australia

Reviewed by:

Bin-Nan Wu,

Kaohsiung Medical University, Taiwan

Beate Rassler,

Leipzig University, Germany

*Correspondence:

Elisabetta Meacci

elisabetta.meacci@unifi.it

tThese authors have contributed

equally to this work.

Specialty section:

This article was submitted to Cardiovascular and Smooth Muscle

Pharmacology,

a section of the journal

Frontiers in Pharmacology

Received: 06 March 2017

Accepted: 10 May 2017

Published: 02 June 2017

Citation:

Vestri A, Pierucci F, Frati $A$,

Monaco L and Meacci E (2017) Sphingosine 1-Phosphate Receptors: Do They Have a Therapeutic Potential

in Cardiac Fibrosis?

Front. Pharmacol. 8:296.

doi: 10.3389/fphar.2017.00296
Sphingosine 1-phosphate (S1P) is a bioactive lipid that is characterized by a peculiar mechanism of action. In fact, S1P, which is produced inside the cell, can act as an intracellular mediator, whereas after its export outside the cell, it can act as ligand of specific G-protein coupled receptors, which were initially named endothelial differentiation gene (Edg) and eventually renamed sphingosine 1-phosphate receptors (S1PRs). Among the five S1PR subtypes, S1PR1, S1PR2 and S1PR3 isoforms show broad tissue gene expression, while S1PR4 is primarily expressed in immune system cells, and S1PR5 is expressed in the central nervous system. There is accumulating evidence for the important role of S1P as a mediator of many processes, such as angiogenesis, carcinogenesis and immunity, and, ultimately, fibrosis. After a tissue injury, the imbalance between the production of extracellular matrix (ECM) and its degradation, which occurs due to chronic inflammatory conditions, leads to an accumulation of ECM and, consequential, organ dysfunction. In these pathological conditions, many factors have been described to act as pro- and anti-fibrotic agents, including S1P. This bioactive lipid exhibits both pro- and anti-fibrotic effects, depending on its site of action. In this review, after a brief description of sphingolipid metabolism and signaling, we emphasize the involvement of the S1P/S1PR axis and the downstream signaling pathways in the development of fibrosis. The current knowledge of the therapeutic potential of S1PR subtype modulators in the treatment of the cardiac functions and fibrinogenesis are also examined.

Keywords: sphingosine 1-phosphate, sphingolipids, matrix metalloproteinases, cardiomyocytes, collagen accumulation, G-coupled receptor, cardiac fibrosis

\section{INTRACELLULAR AND EXTRACELLULAR ACTIONS OF S1P}

Sphingosine 1-phosphate is the intermediate breakdown product of the catabolism of complex SLs (Figure 1), a class of lipids characterized by a C8 carboamide alcohol backbone that was discovered in the brain in 1870 (Thudichum, 1884). S1P is present in the plasma, where it binds to ApoM on HDL particles, and serum albumin (Christoffersen et al., 2011). This bioactive lipid is in all types of mammalian cells (Hannun and Obeid, 2008) and, systemic and local gradients of S1P are essential for immune cell homing (Olivera et al., 2013; Nishi et al., 2014). S1P is formed from Sph by two differently localized and regulated enzyme isoforms, SphK 1 and SphK2 (Maceyka et al., 2012). 
Although SphK1 and SphK2 catalyze the same reaction, SphK1 inhibition/gene ablation decreases blood S1P, while SphK2 inhibition/gene ablation increases blood S1P. At the cellular level, studies have shown the involvement of SphK1 in cell survival and cell growth, whereas SphK2 is rather associated with growth arrest and apoptosis (Liu et al., 2003).

Sphingosine 1-phosphate acts inside cells as a signaling molecule that regulates specific targets (Maceyka et al., 2012), such as PHB2, a highly conserved protein that regulates mitochondrial assembly and function, TRAF-2, which is upregulated in fibroblasts, and NF- $\mathrm{B}$, which is crucially involved in inflammatory gene regulation (Xia et al., 2002; Alvarez et al., 2010).

However, in response to only partially known stimuli, S1P can be transported outside the cells by a specific S1P transporter, named Spns2, and upon binding to one or more of the five subtypes of G-protein-coupled receptors (GPCRs), named S1PR1-5, it triggers many downstream signaling pathways (Zu Heringdorf et al., 2013; Kihara et al., 2014; Nishi et al., 2014) (Table 1). Hla and Maciag (1990), by a differential display method, discovered the orphan GPCR Edg-1, and successively identified as a S1PR1 receptor based on the sequence homology with LPA1/Vzg-1/Edg-2. Later, other receptors, including Edg-5 and Edg-3, followed by Edg-6 and Edg-8 (now termed S1PR2, S1PR3, S1PR4 and S1PR5), were described (An et al., 1997, 2000; Goetzl et al., 1999).

Sphingosine 1-phosphate receptors are widely expressed and specifically coupled to distinct G-proteins as reported in Table 1 (Blaho and Hla, 2014; Kihara et al., 2014; Pyne et al., 2015). Recently, studies on the crystal structure of S1PR1 (Hanson et al., 2012) have indicated that the ligand likely binds the receptor by lateral access (Rosen et al., 2013). Substantial evidence has demonstrated that S1PR-mediated signaling regulates many biological processes, such as cell growth and survival, migration, and adhesion (Maceyka et al., 2012; Kunkel et al., 2013; Proia and Hla, 2015); thus, the impairment of the SphK/S1P/S1PR axis leads

\footnotetext{
Abbreviations: 3KR, 3-keto reductase; AC, adenylate cyclase; Akt, serine/threonine-specific protein kinase 1; ApoM, apolipoprotein M; C1P, ceramide-1-phosphate; cAMP, cyclic adenosine monophosphate; CDase, ceramidase; Cer, ceramide; CerK, ceramide kinase; CerS, ceramide synthase; CTGF, connective tissue growth factor; DeS, desaturase; ECM, extracellular matrix; Edg-1, endothelial differentiation gene-1; eNOS, endothelial nitric oxide synthase; ERK1/2, extracellular signal-regulated kinase 1/2; GIRK, G protein-coupled inwardly rectifying potassium channels; GPCR, G-protein coupled receptors; GTP, guanosine triphosphate; HDAC, histone deacetylase; HDL, high density lipoproteins; IL, interleukin; LPA1, lysophosphatidic acid receptor 1; miR, microRNA; MMP, matrix metalloproteinase; MS, multiple sclerosis; NF$\kappa \mathrm{B}$, nuclear factor kappa-light-chain-enhancer of activated B cell; PDGF, platelet-derived growth factor; PHB2, prohibitin 2; PI3K, phosphatidylinositol4,5-bisphosphate 3-kinase; PLC, phospholipase C; Rho GTPase, Ras homolog GTP hydrolase; RLX, relaxin; ROCK, Rho associated-protein kinase; RXFP1, relaxin/insulin like family peptide receptor 1; S1P, sphingosine 1-phosphate; S1PR, S1P receptor; siRNA, short interfering RNA; SL, sphingolipid; SM, sphingomyelin; SMA, smooth muscle actin; Smad, small mother aganist decapentaplegic; SMase, sphingomyelinase; SMS, sphingomyelin synthase; Sph, sphingosine; SphK, sphingosine kinase; SPL, S1P lyase; Spns2, Spinster 2 (S1P transporter); SPPase, S1P phosphatases; SPT, serine palmitoyl transferase; TGFBR, TGF receptor; TGF $\beta$, transforming growth factor $\beta$; TIMP, tissue inhibitors of metalloproteinase; TNF, tumor necrosis factor; TRAF-2, TNF receptor-associated factor 2; UTR, untranslated region; Vzg-1, ventricular zone gene-1.
}

to many disorders, including inflammation, fibrosis, and cancer (Schwalm et al., 2013, 2015; Newton et al., 2015; Pyne et al., 2015).

\section{CARDIAC FIBROSIS}

Cardiac fibrosis is a multistep disorder, which arises due to several circumstances, such as inflammation, ischaemia and senescence. Myocardial integrity is assured throughout life by fibrotic remodeling of cardiac tissue that becomes decisive in the progression of cardiac disease, thus contributing to the high risk of mortality for this disease (Cohn et al., 2000; Kong et al., 2014; Gyöngyösi et al., 2017).

Fibroblasts, the major producers of cardiac ECM (Krenning et al., 2010), provide the initial structural support in the neonatal heart, respond electrically to mechanical stretch and participate in the synchronization of cardiac tissue (Tomasek et al., 2002). In chronic conditions of ischaemia or altered oxygen tension, angiotensin-aldosterone mediated oxidative/redox stress, pro-inflammatory and pro-fibrotic factors activate circulating bone marrow-derived fibrocytes, epithelial cells and resident fibroblasts that adopt an hypersecretory myofibroblast phenotype (Porter and Turner, 2009; van den Borne et al., 2010; Lajiness and Conway, 2014). Myofibroblasts, by acting in an autocrine/paracrine manner, start to overproduce ECM. Accumulation of abundant type I/III fibrillar collagen and a variety of bioactive substances causes stiffening of the heart and decreased cardiac function (Gyöngyösi et al., 2017). Among the factors involved in the initiation and progression of cardiac fibrosis, transforming growth factor $\beta$ (TGF- $\beta$ ) and the local renin-angiotensin-aldosterone system together with other cytokines, including tumor necrosis factor $\alpha$ (TNF- $\alpha$ ), interleukin 6 (IL-6), and endothelin-1 (Davis and Molkentin, 2014; Bomb et al., 2016), trigger many signaling pathways, such as Smad protein and GTP hydrolase (GTPase) activation (Rosenkranz, 2004; Wynn, 2008; Porter and Turner, 2009; Leask, 2010; Creemers and Pinto, 2011; Wynn and Ramalingam, 2012). In cardiac matrix remodeling, other key players include the zinc-dependent matrix metalloproteinases (MMPs) and tissue inhibitors of metalloproteinases (TIMPs) (Tyagi et al., 1993; Nagase et al., 2006; Spinale, 2007; Mishra et al., 2013). Aberrant levels of different MMPs and TIMPs are highly correlated with cardiac fibrosis (Moshal et al., 2005; Ahmed et al., 2006; Spinale et al., 2013). MMP-2 and MMP-9 have distinct spatial and temporal actions in cardiovascular remodeling; MMP-2 is constitutively expressed, whereas MMP-9 is inducible (Mishra et al., 2013). In addition to their role in ECM degradation, MMPs also act on non-matrix molecules, such as growth factors, allowing local induction-activation of signaling pathways which has been demonstrated after MMP-9 ablation (Mishra et al., 2010). Among the TIMP isoforms (TIMP1-4) implicated in cardiac fibrosis (Vanhoutte and Heymans, 2010), the level of TIMP1 increases in diseased hearts (Heymans et al., 2005) and high levels of TIMP4 are found in parallel to inhibition of MMP9. Modulation of ECM turnover and activation of MMPs and TIMPs are controlled by many factors, including TNF- $\alpha$, TGF- $\beta$ and ILs (Parker and Schneider, 1991; Tsuruda et al., 2004; Wynn 
A

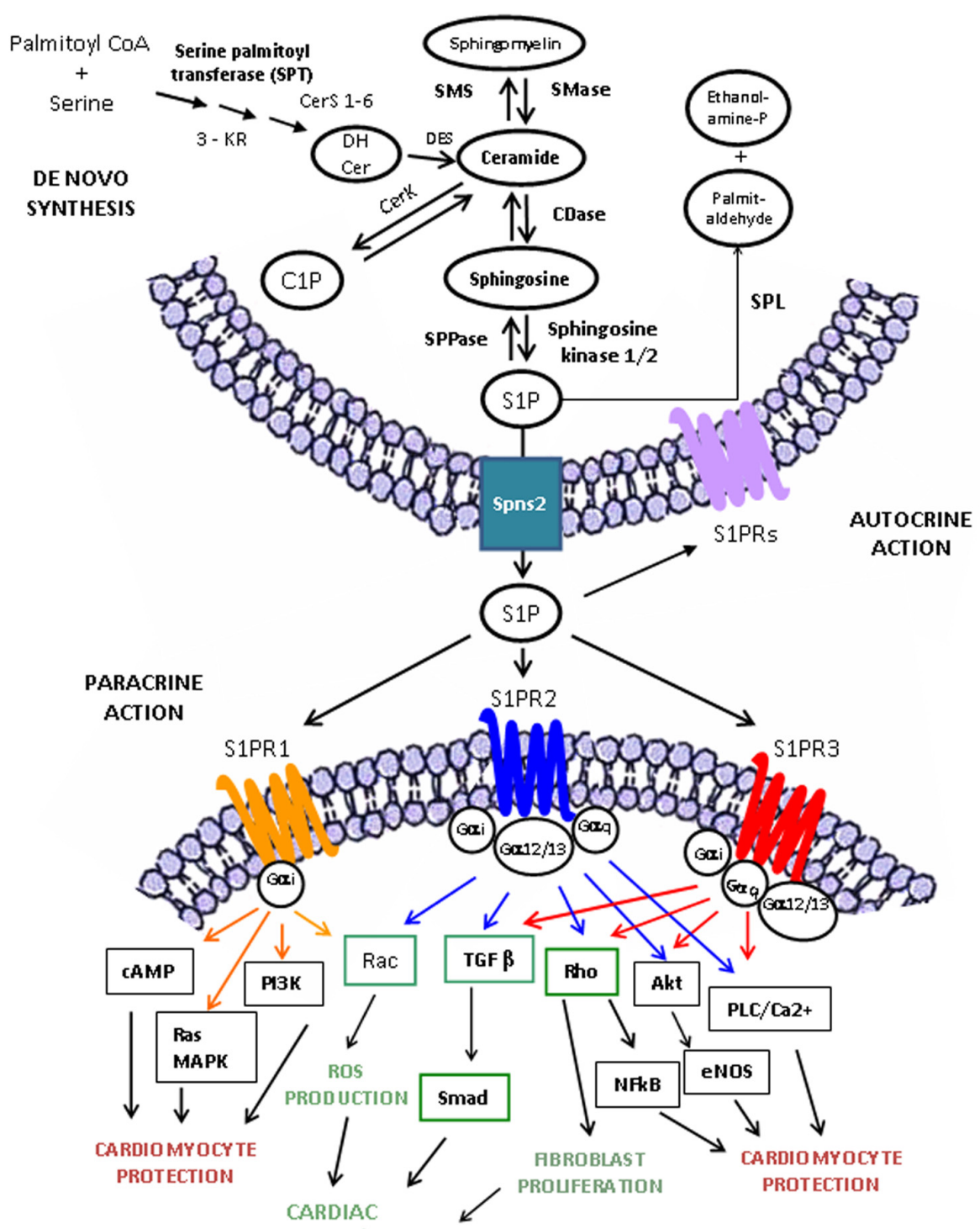

REMODELLING/FIBROSIS

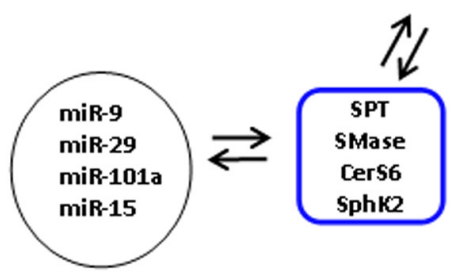

\begin{tabular}{|c|c|c|}
\hline Pro-Fibro & miRs & Anti-Fibrotic miRs \\
\hline $\begin{array}{l}\operatorname{miR}-26^{1} \\
\operatorname{miR}-146^{2}\end{array}$ & ECM remodelling & 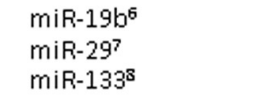 \\
\hline $\begin{array}{l}\operatorname{miR}-21^{3} \\
\operatorname{miR}-34^{4} \\
\text { miR-3285 }\end{array}$ & TGF $\beta /$ Smad signaling & 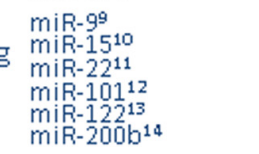 \\
\hline
\end{tabular}

FIGURE 1 | Sphingolipid metabolism, S1P receptor-activated pathways and miR involved in cardiac remodeling and functions. (A) S1P is synthesized from sphingosine (Sph) by the sphingosine kinases, SphK1 and SphK2 and irreversible cleaved by S1P lyase (SPL), which generates hexadecenal and phosphoethanolamine. S1P is also a substrate of specific S1P phosphatases (SPPase). Ceramide derives via the sphingomyelin cycle or de novo sphingolipid synthesis involving serine palmitoyl transferase (SPT), 3-keto reductase (3KR), ceramide synthase (CerS), and desaturase (DeS), and converted reversibly to sphingosine (Sph) by ceramidase (CDase), or phosphorylated to ceramide-1-phosphate (C1P) by ceramide kinase (CerK) activity. S1P produced inside the cell can be transported in the intercellular space by an ATP-binding cassette transporter named spinster homolog 2 (Spns2). As ligand, S1P acts as autocrine and paracrine factor triggering specific signaling pathways by interacting with S1P specific heterotrimeric GTP binding protein-coupled receptors (GPCR), named S1PR. Three 


\section{FIGURE 1 | continued}

among five subtypes of S1PRs, S1PR-1 (orange), -2 (blue), and -3 (red), are expressed in cardiomocytes, cardiac fibroblasts and procursor cardiac cells. In heart, S1PR activation leads to different cardiac effects (profibrotic, green; antifibrotic and cardioprotective, black/red). The scheme exemplifies, in accordance with the current literature, the main pathways triggered by S1PR activation leading to cardiac cell protection and extracellular matrix (ECM) remodeling. Interestingly, the expression of the key enzymes involved in sphingolipid metabolism can be regulated by microRNAs (miRs) and some of them (i.e., miR- $9^{9}$, miR-19b6 ${ }^{6}$ miR- $15^{10}$, and $\mathrm{miR}^{2} \mathbf{2}^{7}$ ) also regulate the fibrotic process by affecting extracellular matrix (ECM) remodeling through the modulation of metalloprotease (MMPs), TGF- $\beta$ /TGFR and Smad protein expression. (B) miRNA in fibrosis. Several miRs have been described as regulators of cardiac fibrosis acting as pro-fibrotic or anti-fibrotic factors on ECM remodeling (black) and on TGF $\beta$ /Smad signaling (blue). ${ }^{\mathbf{1}}$ Wei et al. (2013). ${ }^{\mathbf{2}}$ Wang et al. (2015). ${ }^{\mathbf{3}}$ Thum et al. (2008); Roy et al. (2009), Liang et al. (2012); Dong et al. (2014), He et al. (2016). ${ }^{\mathbf{4}}$ Bernardo et al. (2012); Huang et al. (2014). ${ }^{\mathbf{5}} \mathrm{Du}$ et al. (2016). ${ }^{\mathbf{6}} \mathrm{Zou}$ et al. (2016). ${ }^{\mathbf{7}}$ van Rooij et al. (2008), Abonnenc et al. (2013), Zhang et al. (2014). ${ }^{8}$ Duisters et al. (2009), Castoldi et al. (2012), Chen et al. (2014), Muraoka et al. (2014), Wang et al. (2016). ${ }^{\mathbf{9}} \mathrm{Li}$ et al. (2016). ${ }^{\text {10}}$ Tijsen et al. (2014). ${ }^{11}$ Hong et al. (2016). ${ }^{12}$ Pan et al. (2012). ${ }^{\mathbf{1 3}}$ Beaumont et al. (2014). ${ }^{\mathbf{1 4}}$ Feng et al. (2016).

and Ramalingam, 2012; Gyöngyösi et al., 2017). Among these factors, the hormone peptide relaxin (RLX) is a key regulator of ECM remodeling in reproductive and non-reproductive tissues (Samuel et al., 2007; Du et al., 2010; Nistri et al., 2012). Particularly, RLX inhibits pro-fibrotic cytokines (i.e., TGF- $\beta 1$ ) and modulates the accumulation and degradation of ECM that acts on MMPs and TIMPs (Samuel et al., 2007; Bani et al., 2009; Du et al., 2010; Frati et al., 2015). Moreover, recent research has found that epigenetic factors, such as miRs play an important role in tissue remodeling by controlling MMPs and TGF- $\beta /$ Smad signaling (Figure 1) (Care et al., 2007; Roy et al., 2009; Creemers and van Rooij, 2016; Biglino et al., 2017). Notably, miR expression can also be regulated by MMP-9 (Mishra et al., 2010). Therefore, this class of small non-coding RNAs, which inhibits gene expression by binding the $3^{\prime}$ UTRs of target mRNAs, can be crucial for the fibrotic process, acting as either pro-fibrotic or anti-fibrotic factors. Since dysregulation in miR expression has been reported in myocardial fibrosis (Gurha, 2016), miRs may represent a novel therapeutic strategy to counteract the fibrotic changes that occur in cardiac diseases (Wijnen et al., 2013).

\section{ROLE FOR THE SPHK/S1P AXIS AND S1PR IN CARDIAC FIBROSIS}

Many studies performed in cultured cells as well as in animal models have proposed that S1P possesses cardioprotective effects (Kupperman et al., 2000; Jin et al., 2002; Zhang et al., 2007; Karliner, 2013; Maceyka and Spiegel, 2014). In fact, S1P protects cultured rat neonatal cardiomyocytes from ischaemia-induced cell death (Karliner et al., 2001; Jin et al., 2002). Moreover, mice lacking the enzyme SPL that degrades S1P show reduced sensitivity to ischaemia/reperfusion injury and increased S1P level in both plasma and cardiac tissue (Jin et al., 2011) (Figure 1).

Regarding cardiac fibrosis, SphK1 appears to play a relevant role. SphK1 is induced by TGF- $\beta$ and mediates TIMP-1 upregulation, and siRNA against SphK1 inhibited TGF- $\beta$-stimulated collagen production (Yamanaka et al., 2004; Gellings Lowe et al., 2009). Importantly, the neutralization of extracellular S1P with a specific anti-S1P antibody significantly reduced TGF- $\beta$-stimulated collagen production, indicating the involvement of an "inside-out" signaling of S1P after SphK1 activation in the pro-fibrotic action (Gellings Lowe et al., 2009). Moreover, apelin, an adipocyte-derived factor, inhibits
TGF- $\beta$-stimulated activation of cardiac fibroblasts by reducing SphK1 activity (Pchejetski et al., 2011).

Notably, high S1P production/accumulation in cells is deleterious. In fact, transgenic mice that overexpressed SphK1 at high level develop spontaneous cardiomyocyte degeneration and fibrosis (Tao et al., 2007; Takuwa et al., 2010) and are characterized by increased levels of Rho GTPases and phospho-Smad3, suggesting that these pathways are downstream of SphK1/S1P.

Recently, we have reported that SL metabolism can be activated by RLX at concentrations similar to those previously reported to elicit specific responses in cardiac muscle cells (van der Westhuizen et al., 2008). In both neonatal cardiac cells and H9C2 cells, RLX induces the activation of SphK1 and $\mathrm{S} 1 \mathrm{P}$ production. The silencing and pharmacological inhibition of SphK1 alters the ratio MMPs/TIMPs, and CTGF expression elicited by RLX indicates that hormone peptides promote an ECM-remodeling phenotype through the activation of endogenous S1P production and SM metabolism (Frati et al., 2015).

The role of SphK2 in heart tissue is less clear. Previous research has shown that maternal-zygotic SphK2 is fundamental for cardiac development in zebrafish (Hisano et al., 2015). Moreover, SphK2 knockout sensitizes mouse myocardium to ischaemia/reoxygenation injury (Vessey et al., 2011), and mitochondria obtained from Sphk2 knockout mice exhibit decreased oxidative phosphorylation and increased susceptibility to permeability transition, suggesting a role as protective agent (Gomez et al., 2011). SphK2 appears to be less involved in tissue fibrosis than SphK1 (Schwalm et al., 2015). For example, protein expression of SphK1, but not SphK2, was significantly elevated in lung tissues from patients with idiopathic pulmonary fibrosis (Huang et al., 2013). Presently, the role of SphK2 in cardiac fibrosis is still unclear. Interestingly, Hait et al. (2009) have found that SphK2 is associated with histone $\mathrm{H} 3$, and endogenous S1P that is formed in the nucleus via SphK2 inhibits the action of HDACs (Hait et al., 2009; Ihlefeld et al., 2012). Since HDAC activity is increased in patients with cardiac fibrosis (Liu et al., 2008; Pang and Zhuang, 2010), there is a potential link between SphK2, nuclear S1P and the epigenetic regulation of gene expression that is involved in cardiac fibrosis.

Very recently, a strict correlation between the levels of miRs involved in cardiac fibrosis and SL metabolism has been demonstrated. In fact, SphK, SPT, acid SMase and ceramide synthase 6 (CerS6) can be regulated by several miRs (Figure 1). 


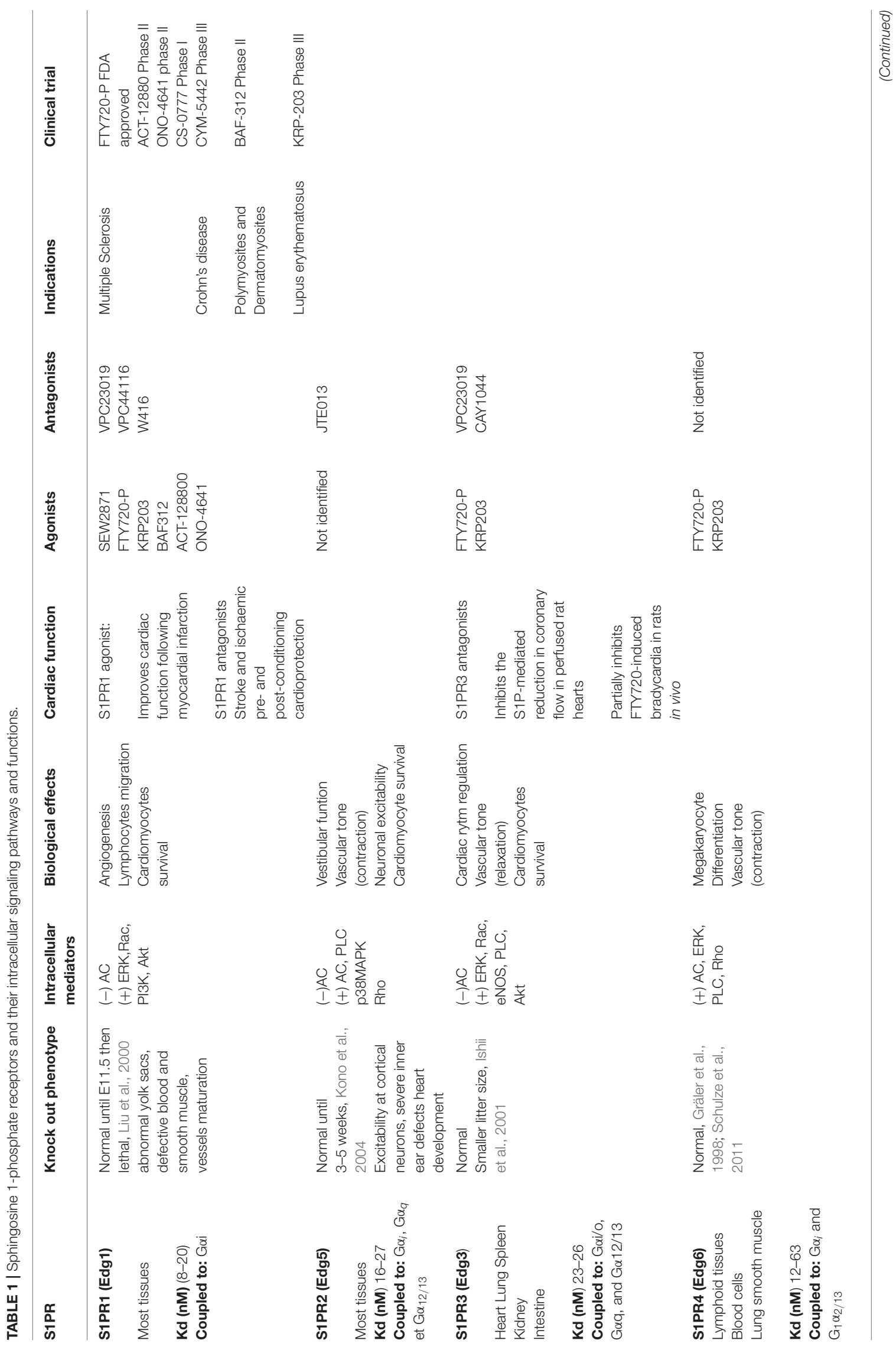


miR-613 and miR-124 inhibit SphK1 (Yu et al., 2017; Zhao et al., 2017). miR-137, miR-181c, miR-9, and miR-29 regulate SPT (Geekiyanage and Chan, 2011). miR-15a modulates acidic SMase (Wang et al., 2015), and miR-101a targets Cer6 (Suzuki et al., 2016) (Figure 1). Interestingly, miR release into exosome particles depends on the ceramide-dependent pathway (Kosaka et al., 2010).

Although the importance of SphK/S1P system has been thoroughly reported, very little is known about the S1P/S1PR axis in the context of cardiac fibrosis. Given that specific anti-S1P antibodies significantly reduce TGF- $\beta$-stimulated collagen production by interfering with the binding of exogenous S1P to its specific receptors, a few years ago, the role of "inside-out" S1P signaling in the fibrotic process was proposed (Gellings Lowe et al., 2009). Three of the five S1PRs (S1PR-1, -2, -3) are the major subtypes expressed in the heart (Peters and Alewijnse, 2007; Means and Brown, 2009). Major candidates for the exogenous S1P-mediated control of the fibrotic process are S1PR2 and S1PR3 (Takuwa et al., 2008, 2010, 2013) that preferentially mediate the two following parallel signaling pathways crucially involved in the fibrotic process: Ras homolog GTPase/Rho-associated-protein kinase (Rho/ROCK) and Smad proteins. Particularly, S1PR3 promotes the activation of Rho signaling and the transactivation of TGF- $\beta$ (Theilmeier et al., 2006; Takuwa et al., 2010). Under chronic activation of SphK1/S1P signaling, S1PR3 mediates pathological cardiac remodeling through ROS production (Takuwa et al., 2010). Moreover, S1PR3-mediated Akt activation protects against in vivo myocardial ischaemia-reperfusion (Means et al., 2007). Characterization of S1PR3-deficient mice also indicates that HDL and S1P promote cardiac protection through nitric oxide/S1PR3 signaling, and exogenous S1P induces intracellular calcium increase through the S1PR3/PLC axis (Theilmeier et al., 2006; Fujii et al., 2014).

Furthermore, S1PR3 can mediate cardioprotection in Langendorff-perfused mouse hearts against ischaemia/ reperfusion injury via Rho/NFkB signaling (Yung et al., 2017). Although, S1PR3 is the most prevalent subtype in cardiac fibroblasts (Takuwa et al., 2013), myofibroblast differentiation and collagen production are mainly mediated by S1PR2 signaling (Schwalm et al., 2013). In fact, the silencing of S1PR2, but not of S1PR1 or S1PR3, can block S1P-mediated $\alpha$-SMA induction (Gellings Lowe et al., 2009), and S1PR2 knock out mice show reduced fibrosis markers expression (Ikeda et al., 2009).

In the heart, the signaling pathways downstream of S1PR1 inhibit cAMP formation and antagonize adrenergic-mediated contractility activation (Means and Brown, 2009). Through S1PR1, S1P induces hypertrophy of cardiomyocytes in vitro (Robert et al., 2001) and decreases vascular permeability (Camerer et al., 2009). In bleomycin-induced injury, S1PR1 functional antagonists increase the pro-fibrotic response (Shea et al., 2010), suggesting an antifibrotic action of S1PR1 in the lung tissue.

There is evidence showing that S1P exhibits cross-talk with pro-fibrotic signaling pathways, such as TGF- $\beta$ (Xin et al., 2004) and PDGF (Alderton et al., 2001). The involvement of S1PRs in the pro-fibrotic effects that are mediated by the cross-talk 
between S1P and TGF- $\beta$ has been demonstrated by inhibition of this effect in primary cardiac fibroblasts by the murine anti-S1P antibody, Sphingomab (Gellings Lowe et al., 2009). Specifically, the role of S1PR3 has been reported in the transactivation of the TGF- $\beta$ /small GTPases system (Takuwa, 2002; Brown et al., 2006). Evidence has also been provided by a study in which the S1PR1 agonists FTY720 mimicked TGF- $\beta$ action by promoting the differentiation of fibroblasts to myofibroblasts, but failed to act on S1PR3 ${ }^{-/-}$fibroblasts (Keller et al., 2007). Differently from TGF- $\beta$, S1P and FTY720-P do not promote Smad signaling to induce ECM synthesis but rather activate PI3K/Akt and ERK1/2 (Sobel et al., 2013). Moreover, TGF- $\beta 2$ stimulates the transactivation of S1PR2 in cardiac fibroblasts, and the silencing of TGF- $\beta$ receptor II or co-Smad 4 reduces the upregulation of CTGF expression induced by FTY720-P in mesangial cells (Xin et al., 2006).

Recently, our group has demonstrated that extracellular S1P inhibits the effects of RLX on MMP-9 release and potentiates hormone action on CTGF expression and TIMP-1 expression through a S1PR subtype-mediated signaling (Frati et al., 2015). Although the action of RLX on S1PRs expression is unknown, a transactivation between S1PRs and the RLX-specific receptor RXFP1 is worthy of investigation (Bathgate et al., 2013).

MicroRNAs can regulate S1PRs in several pathological conditions; for example, S1PR1 expression is upregulated by the deregulation of miR-148a, leading to TGF- $\beta$-dependent epithelial-mesenchymal transition (Heo et al., 2014). TNF- $\alpha$ significantly increases S1PR2 expression in human endothelial cells by reducing miR-130a level (Fan et al., 2016). No data are currently available on the role of miRs that are involved in cardiac fibrosis and S1PR expression.

\section{S1PR MODULATORS IN CARDIAC FUNCTIONS}

\section{S1PR1 Agonists}

Fingolimod (FTY729), synthesized from myriocin, is an immunosuppressive product isolated from Isaria sinclairii and has received approval from the Food and Drug Administration and from the European Medicines Agency as a drug for the treatment of MS (Gilenya, Novartis) (Chun and Hartung, 2010; Chun and Brinkmann, 2011; Cohen and Chun, 2011). The phosphorylated form, phospho-FTY720 (FTY720-P) that is formed by SphK2 in vivo (Brinkmann et al., 2010), is a structural analog of S1P that binds and activates S1PR1-3-4-5, but not S1PR2. Notably, the long-term activation of S1PR1 by FTY720-P determines receptor internalization and degradation, thus acting as a S1PR1 antagonist (Graeler and Goetzl, 2002; Matloubian et al., 2004; Brinkmann et al., 2010; Gonzalez-Cabrera et al., 2012). Due to the binding to various S1PRs, FTY720-P is responsible for several collateral effects on MS patients, such as cardiac effects (bradycardia and atrioventricular block) (Sanna et al., 2004; Camm et al., 2014; Gold et al., 2014). Such effects have been attributed to the activation of S1PR3, and in some cases, to S1PR1. Long-term S1PR1 down-regulation contributes to the disruption of $\mathrm{Ca}^{2+}$ homeostasis and attenuation of ischaemic preconditioning (Keul et al., 2016).

The phosphorylated form of Fingolimod takes part in cardioprotection in heart transplantation related ischaemiareperfusion $(I / R)$ injury (Santos-Gallego et al., 2016) and acting as potent anti-inflammatory (Aytan et al., 2016) and anti-oxidant agents may lead to reduce myocardial damage as a consequence of reduced cardiomyocytes death.

A new selective S1PR modulator, ceralifimod (ONO-4641), has been recently designed and tested for its ability to limit the cardiovascular complications of Fingolimod (Krösser et al., 2015). Similarly, Amiselimod (MT-1303), a second-generation S1PR modulator, has potent selectivity for S1PR1 and S1PR5 and has almost fivefold weaker GIRK activation (G-proteincoupled inwardly rectifying potassium channel) than FTY720-P (Sugahara et al., 2017). Other interesting compounds that can act on cardiac functions have been reviewed elsewhere (Vachal et al., 2006; Guerrero et al., 2016; Xiao et al., 2016) (Table 1). SEW2871 is structurally unrelated to S1P, and its phosphorylation is not required for binding to S1PR1. SEW2871 promotes lymphopenia by reducing inflammatory cells, especially CD4 ${ }^{+}$T cells (Lien et al., 2006), attenuates kidney ischaemia/reperfusion injury (Lai et al., 2007), and improves cardiac functions following myocardial infarction (Yeh et al., 2009). However, some evidence has indicated that SEW2871 can exacerbate reperfusion arrhythmias (Tsukada et al., 2007). SEW2871 and AUY954, an aminocarboxylate analog of FTY720 (Zhang et al., 2009), directly prevent allograft rejection in rat cardiac transplantation through the regulation of lymphocyte trafficking (Pan et al., 2006). Moreover, AUY954 significantly inhibited expressions of IL-17 and MMP-9 in rat sciatic nerves (Zhang et al., 2009). Repeated AUY954 administration enhanced pulmonary fibrosis by inducing vascular leak (Shea et al., 2010), suggesting caution in the use of this drug. CYM-5442, which binds to S1PR1 in a structural hydrophobic pocket different from Fingolimod (Gonzalez-Cabrera et al., 2008), induces lymphopenia and promotes eNOS activation in endothelial cells, thus playing a role in vascular homeostasis (Tölle et al., 2016). Compound 6d lacks S1PR3 agonism and induces lymphopenia with reduced collateral effects on the heart (Hamada et al., 2010). BAF-312 is a next-generation S1PR modulator, which is selective for S1PR1 and S1PR5 (Fryer et al., 2012), and has speciesspecific effects on the heart. BAF-312 induces rapid and transient bradycardia in humans through GIRK activation (Gergely et al., 2012). Notably, different doses may be used to limit cardiac effects (Legangneux et al., 2013). KRP-203 reduced chronic rejection and graft vasculopathy in rat skin and heart allografts (Takahashi et al., 2005), and in an experimental autoimmune myocarditis model, it significantly inhibited the infiltration of immune cells into the myocardium, reducing the area of inflammation (Ogawa et al., 2007). Currently, KRP-203 is undergoing a clinical trial for subacute lupus erythaematosus and in patients undergoing stem cell transplantation for hematological malignancies.

S1PR1 antagonists were reported to have therapeutic potential, but their use requires attention. VPC23019, acting as S1PR1 and S1PR3 antagonist, has been used in ischaemic pre- and post-conditioning cardioprotection that is promoted 
by endogenous S1P in ex vivo rat hearts (Vessey et al., 2009). W-146, which was initially reported to increase the basal leakage of the pulmonary endothelium (Sanna et al., 2006), has been used to demonstrate the role of the S1P pathway in TGF- $\beta 1$-induced expression of $\alpha$-SMA in human fetal lung fibroblasts (Kawashima et al., 2012).

\section{S1PR2 Agonists}

S1PR2 agonists are mainly used in the treatment of hearing loss (Table 1). A study has shown that CYM-5478 has vascular effects, which is indicated by enhanced ischaemia-reperfusion injury in vivo (Satsu et al., 2013).

\section{S1PR2 Antagonists}

JTE-013 was initially reported to affect coronary artery contraction (Ohmori et al., 2003). At long-term S1PR2 antagonism induces several collateral effects, such as a high incidence of B cell lymphoma (Cattoretti et al., 2009).

\section{S1PR3 Antagonists}

Selectively blocking S1PR3 is very difficult. For example, VPC25239 antagonizes both S1PR3 and S1PR1, affecting smooth muscle cell functions, whereas VPC01091 leads to neointimal hyperplasia by preferentially blocking S1PR3 (Wamhoff et al., 2008). Other antagonists for S1PR3 are as follows: CAY10444 (or BML-241) (Koide et al., 2002) that can inhibit the prosurvival effect of HDLs after hypoxia-reoxygenation and TY-52156 that suppresses the bradycardia induced by FTY-720 in vivo and promotes vascular contraction (Murakami et al., 2010).

The therapeutic use of monoclonal antibodies can be a valid alternative to synthetic compounds. A monoclonal antibody, 7H9, functionally blocks S1PR3 activation both in vitro and in vivo (Herr, 2012), reduces the growth of breast cancer tumors and prevents systemic inflammation, representing an effective

\section{REFERENCES}

Abonnenc, M., Nabeebaccus, A. A., Mayr, U., Barallobre-Barreiro, J., Dong, X., Cuello, F., et al. (2013). Extracellular matrix secretion by cardiac fibroblasts: Role of microRNA-29b and microRNA-30c. Circ. Res. 113, 1138-47. doi: 10.1161/CIRCRESAHA.113.302400

Ahmed, S. H., Clark, L. L., Pennington, W. R., Webb, C. S., Bonnema, D. D., Leonardi, A. H., et al. (2006). Matrix metalloproteinases/tissue inhibitors of metalloproteinases: relationship between changes in proteolytic determinants of matrix composition and structural, functional, and clinical manifestations of hypertensive heart disease. Circulation 113, 2089-2096. doi: 10.1161/ CIRCULATIONAHA.105.573865

Alderton, F., Rakhit, S., Kong, K. C., Palmer, T., Sambi, B., Pyne, S., et al. (2001). Tethering of the platelet-derived growth factor beta receptor to G-proteincoupled receptors. A novel platform for integrative signaling by these receptor classes in mammalian cells. J. Biol. Chem. 276, 28578-28585. doi: 10.1074/jbc. M102771200

Alvarez, S. E., Harikumar, K. B., Hait, N. C., Allegood, J., Strub, G. M., Kim, E. Y., et al. (2010). Sphingosine-1-phosphate is a missing cofactor for the E3 ubiquitin ligase TRAF2. Nature 465, 1084-1088. doi: 10.1038/nature 09128

An, S., Bleu, T., Huang, W., Hallmark, O. G., Coughlin, S. R., and Goetzl, E. J. (1997). Identification of cDNAs encoding two G protein-coupled receptors for lysosphingolipids. FEBS Lett. 417, 279-282. doi: 10.1016/S0014-5793(97) 01301-X approach against the morbidity of sepsis (Harris et al., 2012). To date, no specific antagonists for S1PR4 and S1PR5 are available, although (S)-FTY720-vinylphosphonate acts as a pan-antagonist that fully antagonizes S1PR1, S1PR3 and S1PR4 and partially antagonizes S1PR2 and S1PR5 (Valentine et al., 2010).

\section{CONCLUSION}

Targeting S1P signaling might be an intriguing new strategy for the treatment of cardiac fibrosis. However, the double face of the "sphinx" should be carefully considered, and the potential of the multiple collateral effects of S1PR modulators should be evaluated with caution.

\section{AUTHOR CONTRIBUTIONS}

EM and LM have partecipated in design the main structure of the minireview and in the revision of literature and in the preparation of the text. AV, FP, and AF have participated in reviewing the literature and writing the manuscript and prepare the figure.

\section{FUNDING}

This work was supported by grants from Ente Cassa di Risparmio di Firenze to EM and MIUR (ex 60\% Ateneo 2015) to EM.

\section{ACKNOWLEDGMENT}

The authors would like to acknowledge Dr. Maria Rita Calabrese for the support in drawing the figure and table.

An, S., Zheng, Y., and Bleu, T. (2000). Sphingosine 1-phosphate-induced cell proliferation, survival, and related signaling events mediated by G proteincoupled receptors Edg3 and Edg5. J. Biol. Chem. 275, 288-296.

Aytan, N., Choi, J. K., Carreras, I., Brinkmann, V., Kowall, N. W., Jenkins, B. G., et al. (2016). Fingolimod modulates multiple neuroinflammatory markers in a mouse model of Alzheimer's disease. Sci. Rep. 6:24939. doi: 10.1038/srep24939

Bani, D., Nistri, S., Formigli, L., Meacci, E., Francini, F., and Zecchi-Orlandini, S. (2009). Prominent role of relaxin in improving post infarction heart remodeling. Ann. N. Y. Acad. Sci. 1160, 269-277. doi: 10.1111/j.1749-6632. 2008.03781

Bathgate, R. A., Halls, M. L., van der Westhuizen, E. T., Callander, G. E., Kocan, M., and Summers, R. J. (2013). Relaxin family peptides and their receptors. Physiol. Rev. 93, 405-480. doi: 10.1152/physrev.00001.2012

Beaumont, J., López, B., Hermida, N., Schroen, B., San José, G., Heymans, S., et al. (2014). microRNA-122 down-regulation may play a role in severe myocardial fibrosis in human aortic stenosis through TGF-ß1 up-regulation. Clin. Sci. 126, 497-506. doi: 10.1042/CS20130538

Bernardo, B. C., Gao, X. M., Winbanks, C. E., Boey, E. J., Tham, Y. K., Kiriazis, H., et al. (2012). Therapeutic inhibition of the miR-34 family attenuates pathological cardiac remodeling and improves heart function. Proc. Natl. Acad. Sci. U.S.A. 109, 17615-17620. doi: 10.1073/pnas.1206432109

Biglino, G., Caputo, M., Rajakaruna, C., Angelini, G., van Rooij, E., and Emanueli, C. (2017). Modulating microRNAs in cardiac surgery patients: novel therapeutic opportunities? Pharmacol. Ther. 170, 192-204. doi: 10.1016/ j.pharmthera.2016.11.004 
Blaho, V. A., and Hla, T. (2014). An update on the biology of sphingosine 1-phosphate receptors. J. Lipid Res. 55, 1596-1608. doi: 10.1194/jlr.R046300

Bomb, R., Heckle, M. R., Sun, Y., Mancarella, S., Guntaka, R. V., Gerling, I. C., et al. (2016). Myofibroblast secretome and its auto-/paracrine signaling. Expert Rev. Cardiovasc. Ther. 14, 591-598. doi: 10.1586/14779072.2016.1147348

Brinkmann, V., Billich, A., Baumruker, T., Heining, P., Schmouder, R., Francis, G., et al. (2010). Fingolimod (FTY720): discovery and development of an oral drug to treat multiple sclerosis. Nat. Rev. Drug Discov. 9, 883-897. doi: 10.1038/ $\operatorname{nrd} 3248$

Brown, J. H., Del Re, D. P., and Sussman, M. A. (2006). The Rac and Rho hall of fame: a decade of hypertrophic signaling hits. Circ. Res. 98, 730-742. doi: 10.1161/01.RES.0000216039.75913.9e

Camerer, E., Regard, J. B., Cornelissen, I., Srinivasan, Y., Duong, D. N., Palmer, D., et al. (2009). Sphingosine-1-phosphate in the plasma compartment regulates basal and inflammation-induced vascular leak in mice. J. Clin. Invest. 119, 1871-1879. doi: $10.1172 /$ JCI38575

Camm, J., Hla, T., Bakshi, R., and Brinkmann, V. (2014). Cardiac and vascular effects offingolimod: mechanistic basis and clinical implications. Am. Heart J. 168, 632-644. doi: 10.1016/j.ahj.2014.06.028

Care, A., Catalucci, D., Felicetti, F., Bonci, D., Addario, A., Gallo, P., et al. (2007). MicroRNA-133 controls cardiac hypertrophy. Nature Med. 13, 613-618. doi: $10.1038 / \mathrm{nm} 1582$

Castoldi, G., Di Gioia, C. R., Bombardi, C., Catalucci, D., Corradi, B., Gualazzi, M. G., et al. (2012). MiR-133a regulates collagen 1A1: potential role of miR133a in myocardial fibrosis in angiotensin II-dependent hypertension. J. Cell. Physiol. 227, 850-856. doi: 10.1002/jcp.22939

Cattoretti, G., Mandelbaum, J., Lee, N., Chaves, A. H., Mahler, A. M., Chadburn, A., et al. (2009). Targeted disruption of the S1P2 sphingosine 1-phosphate receptor gene leads to diffuse large B-cell lymphoma formation. Cancer Res. 69, 8686-8692. doi: 10.1158/0008-5472.CAN-09-1110

Chen, S., Puthanveetil, P., Feng, B., Matkovich, S. J., Dorn, G. W. II, and Chakrabarti, S. (2014). Cardiac miR-133a overexpression prevents early cardiac fibrosis in diabetes. J. Cell. Mol. Med. 18, 415-421. doi: 10.1111/jcmm.12218

Christoffersen, C., Obinata, H., Kumaraswamy, S. B., Galvani, S., Ahnström, J., Sevvana, M., et al. (2011). Endothelium-protective sphingosine-1-phosphate provided by HDL-associated apolipoprotein M. Proc. Natl. Acad. Sci. U.S.A. 108, 9613-9618. doi: 10.1073/pnas.1103187108

Chun, J., and Brinkmann, V. (2011). A mechanistically novel, first oral therapy for multiple sclerosis: the development of fingolimod (FTY720, Gilenya). Discov. Med. 12, 213-228.

Chun, J., and Hartung, H. P. (2010). Mechanism of action of oral fingolimod (FTY720) in multiple sclerosis. Clin. Neuropharmacol. 33, 91-101. doi: 10.1097/ WNF.0b013e3181cbf825

Cohen, J. A., and Chun, J. (2011). Mechanisms of fingolimod's efficacy and adverse effects in multiple sclerosis. Ann. Neurol. 69, 759-777. doi: 10.1002/ana.22426

Cohn, J. N., Ferrari, R., and Sharpe, N. (2000). Cardiac remodeling-concepts and clinical implications: a consensus paper from an international forum on cardiac remodeling. Behalf of an international forum on cardiac remodeling. J. Am. Coll. Cardiol. 35, 569-582. doi: 10.1016/S0735-1097(99) 00630-0

Creemers, E. E., and Pinto, Y. M. (2011). Molecular mechanisms that control interstitial fibrosis in the pressure-overloaded heart. Cardiovasc. Res. 89, 265-272. doi: $10.1093 / \mathrm{cvr} / \mathrm{cvq} 308$

Creemers, E. E., and van Rooij, E. (2016). Function and therapeutic potential of noncoding RNAs in cardiac fibrosis. Circ. Res. 118, 108-118. doi: 10.1161/ CIRCRESAHA.115.305242

Davis, J., and Molkentin, J. D. (2014). Myofibroblasts: trust your heart and let fate decide. J. Mol. Cell. Cardiol. 70, 9-18. doi: 10.1016/j.yjmcc.2013.10.019

Dong, S., Ma, W., Hao, B., Hu, F., Yan, L., Yan, X., et al. (2014). MicroRNA-21 promotes cardiac fibrosis and development of heart failure with preserved left ventricular ejection fraction by up-regulating Bcl-2. Int. J. Clin. Exp. Pathol. 7, 565-574.

Du, X. J., Bathgate, R. A., Samuel, C. S., Dart, A. M., and Summers, R. J. (2010). Cardiovascular effects of relaxin: from basic science to clinical therapy. Nat. Rev. Cardiol. 7, 48-58. doi: 10.1038/nrcardio.2009.198

Du, W., Liang, H., Gao, X., Li, X., Zhang, Y., Pan, Z., et al. (2016). MicroRNA-328, a potential anti-fibrotic target in cardiac interstitial fibrosis. Cell Physiol. Biochem. 39, 827-836. doi: $10.1159 / 000447793$
Duisters, R. F., Tijsen, A. J., Schroen, B., Leenders, J. J., Lentink, V., van der Made, I., et al. (2009). miR-133 and miR-30 regulate connective tissue growth factor: implications for a role of microRNAs in myocardial matrix remodeling. Circ. Res. 104, 170-178. doi: 10.1161/CIRCRESAHA.108.182535

Fan, A., Wang, Q., Yuan, Y., Cheng, J., Chen, L., Guo, X., et al. (2016). Liver X receptor- $\alpha$ and miR-130a-3p regulate expression of sphingosine 1-phosphate receptor 2 in human umbilical vein endothelial cells. Am. J. Physiol. Cell. Physiol. 310, C216-C226. doi: 10.1152/ajpcell.00102.2015

Feng, B., Cao, Y., Chen, S., Chu, X., Chu, Y., and Chakrabarti, S. (2016). miR-200b mediates endothelial-to-mesenchymal transition in diabetic cardiomyopathy. Diabetes Metab. Res. Rev. 65, 768-779. doi: 10.2337/db15-1033

Frati, A., Ricci, B., Pierucci, F., Nistri, S., Bani, D., and Meacci, E. (2015). Role of sphingosine kinase/S1P axis in ECM remodeling of cardiac cells elicited by relaxin. Mol. Endocrinol. 29, 53-67. doi: 10.1210/me.2014-1201

Fryer, R. M., Muthukumarana, A., Harrison, P. C., Nodop Mazurek, S., Chen, R. R., Harrington, K. E., et al. (2012). The clinically-tested S1P receptor agonists, FTY720 and BAF312, demonstrate subtype-specific bradycardia (S1P1) and hypertension (S1P3) in rat. PLoS ONE 7:e52985. doi: 10.1371/journal.pone. 0052985

Fujii, K., Machida, T., Iizuka, K., and Hirafuji, M. (2014). Sphingosine 1-phosphate increases an intracellular $\mathrm{Ca} 2+$ concentration via S1P3 receptor in cultured vascular smooth muscle cells. J. Pharm. Pharmacol. 66, 802-810. doi: 10.1111/ jphp. 12214

Geekiyanage, H., and Chan, C. (2011). MicroRNA-137/181c regulates serine palmitoyltransferase and in turn amyloid beta, novel targets in sporadic Alzheimer's disease. J. Neurosci. 31, 14820-14830. doi: 10.1523/JNEUROSCI. 3883-11.2011

Gellings Lowe, N. G., Swaney, J. S., Moreno, K. M., and Sabbadini, R. A. (2009). Sphingosine-1-phosphate and sphingosine kinase are critical for TGF$\beta$-stimulated collagen production by cardiac fibroblasts. Cardiovasc. Res. 82 , 303-312. doi: 10.1093/cvr/cvp056

Gergely, P., Nuesslein-Hildesheim, B., Guerini, D., Brinkmann, V., Traebert, M., Bruns, C., et al. (2012). The selective sphingosine 1-phosphate receptor modulator BAF312 redirects lymphocyte distribution and has species-specific effects on heart rate. Br. J. Pharmacol. 167, 1035-1047. doi: 10.1111/j.1476-5381. 2012.02061.x

Goetzl, E. J., Dolezalova, H., Kong, Y., Hu, Y. L., Jaffe, R. B., Kalli, K. R., et al. (1999). Distinctive expression and functions of the type 4 endothelial differentiation gene-encoded $\mathrm{G}$ protein-coupled receptor for lysophosphatidic acid in ovarian cancer. Cancer Res. 59, 5370-5375.

Gold, R., Comi, G., Palace, J., Siever, A., Gottschalk, R., Bijarnia, M., et al. (2014). Assessment of cardiac safety during fingolimod treatment initiation in a realworld relapsing multiple sclerosis population: a phase $3 \mathrm{~b}$, open-label study. J. Neurol. 261, 267-276. doi: 10.1007/s00415-013-7115-8

Gomez, L., Paillard, M., Price, M., Chen, Q., Teixeira, G., Spiegel, S., et al. (2011). A novel role for mitochondrial sphingosine-1-phosphate produced by, sphingosine kinase-2, in PTP-mediated cell survival during cardioprotection. Basic Res. Cardiol. 106, 1341-1353. doi: 10.1007/s00395-011-0223-7

Gonzalez-Cabrera, P. J., Cahalan, S. M., Nguyen, N., Sarkisyan, G., Leaf, N. B., Cameron, M. D., et al. (2012). S1P(1) receptor modulation with cyclical recovery from lymphopenia ameliorates mouse model of multiple sclerosis. Mol. Pharmacol. 81, 166-174. doi: 10.1124/mol.111.076109

Gonzalez-Cabrera, P. J., Jo, E., Sanna, M. G., Brown, S., Leaf, N., Marsolais, D., et al. (2008). Full pharmacological efficacy of a novel S1P1 agonist that does not require S1P-like headgroup interactions. Mol. Pharmacol. 74, 1308-1318. doi: $10.1124 / \mathrm{mol} .108 .049783$

Graeler, M., and Goetzl, E. J. (2002). Activation-regulated expression and chemotactic function of sphingosine 1-phosphate receptors in mouse splenic T cells. FASEB J. 16, 1874-1878. doi: 10.1096/fj.02-0548com

Gräler, M. H., Bernhardt, G., and Lipp, M. (1998). EDG6, a novel G-proteincoupled receptor related to receptors for bioactive lysophospholipids, is specifically expressed in lymphoid tissue. Genomics 53, 164-169. doi: 10.1006/ geno.1998.5491

Guerrero, M., Urbano, M., and Roberts, E. (2016). Sphingosine 1-phosphate receptor 1 agonists: a patent review. Expert Opin. Ther. Pat. 26, 455-470. doi: $10.1517 / 13543776.2016 .1157165$

Gurha, P. (2016). MicroRNAs in cardiovascular disease. Curr. Opin. Cardiol. 31, 249-254. doi: 10.1097/HCO.0000000000000280 
Gyöngyösi, M., Winkler, J., Ramos, I., Do, Q. T., Firat, H., McDonald, K., et al. (2017). Myocardial fibrosis: biomedical research from bench to bedside. Eur. J. Heart Fail. 19, 177-191. doi: 10.1002/ejhf.696

Hait, N. C., Allegood, J., Maceyka, M., Strub, G. M., Harikumar, K. B., Singh, S. K., et al. (2009). Regulation of histone acetylation in the nucleus by sphingosine-1phosphate. Science 325, 1254-1257. doi: 10.1126/science.1176709

Hamada, M., Nakamura, M., Kiuchi, M., Marukawa, K., Tomatsu, A., Shimano, K., et al. (2010). Removal of sphingosine 1-phosphate receptor-3 (S1P3) agonism is essential, but inadequate to obtain immunomodulating 2-aminopropane1,3-diol S1P1 agonists with reduced effect on heart rate. J. Med. Chem. 53, 3154-3168. doi: 10.1021/jm901776q

Hannun, Y. A., and Obeid, L. M. (2008). Principles of bioactive lipid signaling: lessons from sphingolipids. Nature Rev. Mol. Cell Biol. 9, 139-150. doi: 10.1038/ nrm2329

Hanson, M. A., Roth, C. B., Jo, E., Griffith, M. T., Scott, F. L., Reinhart, G., et al. (2012). Crystal structure of a lipid G protein-coupled receptor. Science 335, 851-855. doi: 10.1126/science.1215904

Harris, G. L., Creason, M. B., Brulte, G. B., and Herr, D. R. (2012). In vitro and in vivo antagonism of a G protein-coupled receptor (S1P3) with a novel blocking monoclonal antibody. PLoS ONE 7:e35129. doi: 10.1371/journal.pone. 0035129

He, X., Zhang, K., Gao, X., Li, L., Tan, H., Chen, J., et al. (2016). Rapid atrial pacing induces myocardial fibrosis by down-regulating Smad7 via microRNA-21 in rabbit. Heart Vessels 31, 1696-1708. doi: 10.1007/s00380-016-0808-z

Heo, M. J., Kim, Y. M., Koo, J. H., Yang, Y. M., An, J., Lee, S. K., et al. (2014). microRNA-148a dysregulation discriminates poor prognosis of hepatocellular carcinoma in association with USP4 overexpression. Oncotarget 5, 2792-2806. doi: 10.18632/oncotarget.1920

Herr, D. R. (2012). Potential use of G protein-coupled receptor-blocking monoclonal antibodies as therapeutic agents for cancers. Int. Rev. Cell Mol. Biol. 297, 45-81. doi: 10.1016/B978-0-12-394308-8.00002-9

Heymans, S., Schroen, B., Vermeersch, P., Milting, H., Gao, F., Kassner, A., et al. (2005). Increased cardiac expression of tissue inhibitor of metalloproteinase1 and tissue inhibitor of metalloproteinase- 2 is related to cardiac fibrosis and dysfunction in the chronic pressure-overloaded human heart. Circulation 112, 1136-1144. doi: 10.1161/CIRCULATIONAHA.104.516963

Hisano, Y., Inoue, A., Okudaira, M., Taimatsu, K., Matsumoto, H., Kotani, H., et al. (2015). Maternal and zygotic sphingosine kinase 2 are indispensable for cardiac development in zebrafish. J. Biol. Chem. 290, 14841-14851. doi: 10.1074/jbc. M114.634717

Hla, T., and Maciag, T. (1990). An abundant transcript induced in differentiating human endothelial cells encodes a polypeptide with structural similarities to G-protein-coupled receptors. J. Biol. Chem. 265, 9308-9313.

Hong, Y., Cao, H., Wang, Q., Ye, J., Sui, L., Feng, J., et al. (2016). MiR-22 may suppress fibrogenesis by targeting TGF $\beta$ R I in cardiac fibroblasts. Cell. Physiol. Biochem. 40, 1345-1353. doi: 10.1159/000453187

Huang, L. S., Berdyshev, E., Mathew, B., Fu, P., Gorshkova, I. A., He, D., et al. (2013). Targeting sphingosine kinase 1 attenuates bleomycin-induced pulmonary fibrosis. FASEB J. 27, 1749-1760. doi: 10.1096/fj.12-219634

Huang, Y., Qi, Y., Du, J. Q., and Zhang, D. F. (2014). MicroRNA-34a regulates cardiac fibrosis after myocardial infarction by targeting Smad4. Expert Opin. Ther. Targets 18, 1355-1365. doi: 10.1517/14728222.2014.961424

Ihlefeld, K., Claas, R. F., Koch, A., Pfeilschifter, J. M., and Zu Heringdorf, D. M. (2012). Evidence for a link between histone deacetylation and $\mathrm{Ca}^{2}+$ homoeostasis in sphingosine-1-phosphate lyase-deficient fibroblasts. Biochem. J. 447, 457-464. doi: 10.1042/BJ20120811

Ikeda, H., Watanabe, N., Ishii, I., Shimosawa, T., Kume, Y., Tomiya, T., et al. (2009). Sphingosine 1-phosphate regulates regeneration and fibrosis after liver injury via sphingosine 1-phosphate receptor 2. J. Lipid Res. 50, 556-564. doi: 10.1194/jlr.M800496-JLR200

Im, D. S., Clemens, J., Macdonald, T. L., and Lynch, K. R. (2001). Characterization of the human and mouse sphingosine 1-phosphate receptor, S1P5 (Edg-8): structure-activity relationship of sphingosine1-phosphate receptors. Biochemistry 40, 14053-14060.

Ishii, I., Friedman, B., Ye, X., Kawamura, S., McGiffert, C., Contos, J. J., et al. (2001). Selective loss of sphingosine 1-phosphate signaling with no obvious phenotypic abnormality in mice lacking its G protein-coupled receptor, LP(B3)/EDG-3. J. Biol. Chem. 276, 33697-33704. doi: 10.1074/jbc.M104441200
Jin, Z. Q., Fyrst, H., Zhang, M., Borowsky, A. D., Dillard, L., Karliner, J. S., et al. (2011). S1P lyase: a novel therapeutic target for ischemia-reperfusion injury of the heart. Am. J. Physiol. Heart Circ. Physiol. 300, H1753-H1761. doi: 10.1152/ajpheart.00946.2010

Jin, Z. Q., Zhou, H. Z., Zhu, P., Honbo, N., Mochly-Rosen, D., Messing, R. O., et al. (2002). Cardioprotection mediated by sphingosine-1-phosphate and ganglioside GM-1 in wild-type and PKC epsilon knockout mouse hearts. Am. J. Physiol. Heart Circ. Physiol. 282, H1970-H1977. doi: 10.1152/ajpheart.01029. 2001

Karliner, J. S. (2013). Sphingosine kinase and sphingosine 1-phosphate in the heart: a decade of progress. Biochim. Biophys. Acta 1831, 203-212. doi: 10.1016/j. bbalip.2012.06.006

Karliner, S., Honbo, N., Summers, K., Gray, M. O., and Goetzl, E. J. (2001). The lysophospholipids sphingosine-1-phosphate and lysophosphatidic acid enhance survival during hypoxia in neonatal rat cardiac myocytes. J. Mol. Cell. Cardiol. 33, 1713-1717. doi: 10.1006/jmcc.2001.1429

Kawashima, T., Yamazaki, R., Matsuzawa, Y., Yamaura, E., Takabatake, M., Otake, S., et al. (2012). Contrary effects of sphingosine-1-phosphate on expression of $\alpha$-smooth muscle actin in transforming growth factor B1-stimulated lung fibroblasts. Eur. J. Pharmacol. 696, 120-129. doi: 10.1016/ j.ejphar.2012.09.038

Keller, C. D., Rivera Gil, P., Tölle, M., van der Giet, M., Chun, J., Radeke, H. H., et al. (2007). Immunomodulator FTY720 induces myofibroblast differentiation via the lysophospholipid receptor S1P3 and Smad3 signaling. Am. J. Pathol. 170, 281-229. doi: 10.2353/ajpath.2007.060485

Keul, P., van Borren, M. M., Ghanem, A., Muller, F. U., Baartscheer, A., Verkerk, A. O., et al. (2016). Sphingosine-1-phosphate receptor 1 regulates cardiacfunction by modulating $\mathrm{Ca}^{2+}$ sensitivity and $\mathrm{Na}^{+} / \mathrm{H}^{+}$exchange and mediates protection by ischemic preconditioning. J. Am. Heart. Assoc. 5:e003393. doi: 10.1161/JAHA.116.003393

Kihara, Y., Maceyka, M., Spiegel, S., and Chun, J. (2014). Lysophospholipid receptor nomenclature review: IUPHAR review 8. Br. J. Pharmacol. 171, 3575-3594. doi: 10.1111/bph.12678

Koide, Y., Hasegawa, T., Takahashi, A., Endo, A., Mochizuki, N., Nakagawa, M., et al. (2002). Development of novel EDG3 antagonists using a 3D database search and their structure-activity relationships. J. Med. Chem. 45, 4629-4638. doi: $10.1021 /$ jm020080c

Kong, P., Christia, P., and Frangogiannis, N. (2014). The pathogenesis of cardiac Fibrosis. Cell. Mol. Life Sci. 71, 549-574. doi: 10.1007/s00018-013-1349-6

Kono, M., Mi, Y., Liu, Y., Sasaki, T., Allende, M. L., Wu, Y. P., et al. (2004). The sphingosine-1-phosphate receptors S1P1, S1P2, and S1P3 function coordinately during embryonic angiogenesis. J. Biol. Chem. 279, 29367-29373. doi: 10.1074/ jbc.M403937200

Kosaka, N., Iguchi, H., Yoshioka, Y., Takeshita, F., Matsuki, Y., and Ochiya, T. (2010). Secretory mechanisms and intercellular transfer of microRNAs in living cells. J. Biol. Chem. 285, 17442-17452. doi: 10.1074/jbc.M110.107821

Krenning, G., Zeisberg, E. M., and Kalluri, R. (2010). The origin of fibroblasts and mechanism of cardiac fibrosis. J. Cell. Physiol. 225, 631-637. doi: 10.1002/jcp. 22322

Krösser, S., Wolna, P., Fischer, T. Z., Boschert, U., Stoltz, R., Zhou, M., et al. (2015). Effect of ceralifimod (ONO-4641) on lymphocytes and cardiac function: randomized, double-blind, placebo-controlled trial with an openlabel fingolimod arm. J. Clin. Pharmacol. 55, 1051-1060. doi: 10.1002/ jcph. 513

Kunkel, G. T., Maceyka, M., Milstien, S., and Spiegel, S. (2013). Targeting the sphingosine-1-phosphate axis in cancer, inflammation and beyond. Nat. Rev. Drug Discov. 12, 688-702. doi: 10.1038/nrd4099

Kupperman, E., An, S., Osborne, N., Waldron, S., and Stainier, D. Y. (2000). A sphingosine-1-phosphate receptor regulates cell migration during vertebrate heart development. Nature 406, 192-195. doi: 10.1038/3501 8092

Lai, L. W., Yong, K. C., Igarashi, S., and Lien, Y. H. (2007). A sphingosine-1phosphate type 1 receptor agonist inhibits the early T-cell transient following renal ischemia-reperfusion injury. Kidney Int. 71, 1223-1231. doi: 10.1038/sj.ki. 5002203

Lajiness, J. D., and Conway, S. J. (2014). Origin, development, and differentiation of cardiac fibroblasts. J. Mol. Cell. Cardiol. 70, 2-8. doi: 10.1016/j.yjmcc.2013. 11.003 
Leask, A. (2010). Potential therapeutic targets for cardiac fibrosis: TGFbeta, angiotensin, endothelin, CCN2, and PDGF, partners in fibroblast activation. Circ. Res. 106, 1675-1680. doi: 10.1161/CIRCRESAHA.110.217737

Legangneux, E., Gardin, A., and Johns, D. (2013). Dose titration of BAF312 attenuates the initial heart rate reducing effect in healthy subjects. Br. J. Clin. Pharmacol. 75, 831-841. doi: 10.1111/j.1365-2125.2012.04400.x

Li, J., Dai, Y., Su, Z., and Wei, G. (2016). MicroRNA-9 inhibits high glucose-induced proliferation, differentiation and collagen accumulation of cardiac fibroblasts by down-regulation of TGFBR2. Biosci. Rep. 36, e00417. doi: 10.1042/BSR20160346

Liang, H., Zhang, C., Ban, T., Liu, Y., Mei, L., Piao, X., et al. (2012). A novel reciprocal loop between microRNA-21 and TGFbetaRIII is involved in cardiac fibrosis. Int. J. Biochem. Cell Biol. 44, 2152-2160. doi: 10.1016/j.biocel.2012. 08.019

Lien, Y. H., Yong, K. C., Cho, C., Igarashi, S., and Lai, L. W. (2006). S1P(1)selective agonist, SEW2871, ameliorates ischemic acute renal failure. Kidney Int. 69, 1601-1608. doi: 10.1038/sj.ki.5000360

Liu, F., Levin, M. D., Petrenko, N. B., Lu, M. M., Wang, T., Yuan, L. J., et al. (2008). Histone-deacetylase inhibition reverses atrial arrhythmia inducibility and fibrosis in cardiac hypertrophy independent of angiotensin. J. Mol. Cell. Cardiol. 45, 715-723. doi: 10.1016/j.yjmcc.2008.08.015

Liu, H., Toman, R. E., Goparaju, S. K., Maceyka, M., Nava, V. E., Sankala, H., et al. (2003). Sphingosine kinase type 2 is a putative $\mathrm{BH} 3$-only protein that induces apoptosis. J. Biol. Chem. 278, 40330-40336. doi: 10.1074/jbc.M304455200

Liu, Y., Wada, R., Yamashita, T., Mi, Y., Deng, C. X., Hobson, J. P., et al. (2000). Edg-1, the G protein-coupled receptor for sphingosine-1-phosphate, is essential for vascular maturation. J. Clin. Invest. 106, 951-961. doi: 10.1172/JCI10905

Maceyka, M., Harikumar, K. B., Milstien, S., and Spiegel, S. (2012). Sphingosine1-phosphate signaling and its role in disease. Trends Cell Biol. 22, 50-60. doi: $10.1016 /$ j.tcb. 2011.09 .003

Maceyka, M., and Spiegel, S. (2014). Sphingolipid metabolites in inflammatory disease. Nature 510, 58-67. doi: 10.1038/nature 13475

Matloubian, M., Lo, C. G., Cinamon, G., Lesneski, M. J., Xu, Y., Brinkmann, V., et al. (2004). Lymphocyte egress from thymus and peripheral lymphoid organs is dependent on S1P receptor 1. Nature 427, 355-356. doi: 10.1038/nature02284

Means, C. K., and Brown, J. H. (2009). Sphingosine-1-phosphate receptor signaling in the heart. Cardiovasc. Res. 82, 193-200. doi: 10.1093/cvr/cvp086

Means, C. K., Xiao, C. Y., Li, Z., Zhang, T., Omens, J. H., Ishii, I., et al. (2007). Sphingosine 1-phosphate S1P2 and S1P3 receptor-mediated Akt activation protects against in vivo myocardial ischemia-reperfusion injury. Am. J. Physiol. Heart Circ. Physiol. 292, H2944-H2951.

Mishra, P. K., Givvimani, S., Chavali, V., and Tyagi, S. C. (2013). Cardiac matrix: a clue for future therapy. Biochim. Biophys. Acta 1832, 2271-2276. doi: 10.1016/j. bbadis.2013.09.004

Mishra, P. K., Metreveli, N., and Tyagi, S. C. (2010). MMP-9 gene ablation and TIMP-4 mitigate PAR-1-mediated cardiomyocyte dysfunction: a plausible role of dicer and miRNA. Cell Biochem. Biophys. 57, 67-76. doi: 10.1007/s12013010-9084-1

Moshal, K. S., Tyagi, N., Moss, V., Henderson, B., Steed, M., Ovechkin, A., et al. (2005). Early induction of matrix metalloproteinase- 9 transduces signaling in human heart end stage failure. J. Cell. Mol. Med. 9, 704-713. doi: 10.1111/j. 1582-4934.2005.tb00501.x

Murakami, A., Takasugi, H., Ohnuma, S., Koide, Y., Sakurai, A., Takeda, S., et al. (2010). Sphingosine 1-phosphate (S1P) regulates vascular contraction via S1P3 receptor: investigation based on a new S1P3 receptor antagonist. Mol. Pharmacol. 77, 704-713. doi: 10.1124/mol.109.061481

Muraoka, N., Yamakawa, H., Miyamoto, K., Sadahiro, T., Umei, T., Isomi, M., et al. (2014). MiR-133 promotes cardiac reprogramming by directly repressing Snail and silencing fibroblast signatures. EMBO J. 33, 1565-1581. doi: 10.15252/embj. 201387605

Nagase, H., Visse, R., and Murphy, G. (2006). Structure and function of matrix metalloproteinases and TIMPs. Cardiovasc. Res. 69, 562-573. doi: 10.1016/j. cardiores.2005.12.002

Newton, J., Lima, S., Maceyka, M., and Spiegel, S. (2015). Revisiting the sphingolipid rheostat: evolving concepts in cancer therapy. Exp. Cell Res. 333, 195-200. doi: 10.1016/j.yexcr.2015.02.025

Nishi, T., Kobayashi, N., Hisano, Y., Kawahara, A., and Yamaguchi, A. (2014). Molecular and physiological functions of sphingosine 1-phosphate transporters. Biochim. Biophys. Acta 1841, 759-765. doi: 10.1016/j.bbalip.2013. 07.012

Nistri, S., Pini, A., Sassoli, C., Squecco, R., Francini, F., Formigli, L., et al. (2012). Relaxin promotes growth and maturation of mouse neonatal cardiomyocytes in vitro: clues for cardiac regeneration. J. Cell. Mol. Med. 16, 507-519. doi: $10.1111 / j .1582-4934.2011 .01328 . x$

Ogawa, R., Takahashi, M., Hirose, S., Morimoto, H., Ise, H., Murakami, T., et al. (2007). A novel sphingosine-1-phosphate receptor agonist KRP-203 attenuates rat autoimmune myocarditis. Biochem. Biophys. Res. Commun. 361, 621-628. doi: 10.1016/j.bbrc.2007.07.061

Ohmori, T., Yatomi, Y., Osada, M., Kazama, F., Takafuta, T., Ikeda, H., et al. (2003). Sphingosine 1-phosphate induces contraction of coronary artery smooth muscle cells via S1P2. Cardiovasc. Res. 58, 170-177. doi: 10.1016/S00086363(03)00260-8

Olivera, A., Allende, M. L., and Proia, R. L. (2013). Shaping the landscape: metabolic regulation of S1P gradients. Biochim. Biophys. Acta 1831, 193-202. doi: 10.1016/j.bbalip.2012.06.007

Pan, S., Mi, Y., Pally, C., Beerli, C., Chen, A., Guerini, D., et al. (2006). A monoselective sphingosine-1-phosphate receptor-1 agonist prevents allograft rejection in a stringent rat heart transplantation model. Chem. Biol. 13, 1227-1234. doi: 10.1016/j.chembiol.2006.09.017

Pan, Z., Sun, X., Shan, H., Wang, N., Wang, J., Ren, J., et al. (2012). MicroRNA-101 inhibited postinfarct cardiac fibrosis and improved left ventricular compliance via the FBJ osteosarcoma oncogene/transforming growth factor-betal pathway. Circulation 126, 840-850. doi: 10.1161/CIRCULATIONAHA.112.094524

Pang, M., and Zhuang, S. (2010). Histone deacetylase: a potential therapeutic target for fibrotic disorders. J. Pharmacol. Exp. Ther. 335, 266-272. doi: 10.1124/jpet. 110.168385

Parker, T. G., and Schneider, M. D. (1991). Growth factors, proto-oncogenes, and plasticity of the cardiac phenotype. Annu. Rev. Physiol. 53, 179-200. doi: 10.1146/annurev.ph.53.030191.001143

Pchejetski, D., Foussal, C., Alfarano, C., Lairez, O., Calise, D., Guilbeau-Frugier, C., et al. (2011). Apelin prevents cardiac fibroblast activation and collagen production through inhibition of sphingosine kinase 1. Eur. Heart J. 33, 2360-2369. doi: 10.1093/eurheartj/ehr389

Peters, S. L., and Alewijnse, A. E. (2007). Sphingosine-1-phosphate signaling in the cardiovascular system. Curr. Opin. Pharmacol. 7, 186-192. doi: 10.1016/j.coph. 2006.09.008

Porter, K. E., and Turner, N. A. (2009). Cardiac fibroblasts: at the heart of myocardial remodeling. Pharmacol. Ther. 123, 255-278. doi: 10.1016/j. pharmthera.2009.05.002

Proia, R. L., and Hla, T. (2015). Emerging biology of sphingosine-1-phosphate: its role in pathogenesis and therapy. J. Clin. Invest. 125, 1379-1387. doi: 10.1172/ JCI76369

Pyne, N. J., McNaughton, M., Boomkamp, S., MacRitchie, N., Evangelisti, C., Martelli, A. M., et al. (2015). Role of sphingosine 1-phosphate receptors, sphingosine kinases and sphingosine in cancer and inflammation. Adv. Biol. Regul. 60, 151-159. doi: 10.1016/j.jbior.2015.09.001

Robert, P., Tsui, P., Laville, M. P., Livi, G. P., Sarau, H. M., Bril, A., et al. (2001). EDG1 receptor stimulation leads to cardiac hypertrophy in rat neonatal myocytes. J. Mol. Cell. Cardiol. 33, 1589-1606. doi: 10.1006/jmcc.2001.1433

Rosen, H., Stevens, R. C., Hanson, M., Roberts, E., and Oldstone, M. B. (2013). Sphingosine-1-phosphate and its receptors: structure, signaling, and influence. Аnnu. Rev. Biochem. 82, 637-662. doi: 10.1146/annurev-biochem-062411130916

Rosenkranz, S. (2004). TGF- $\beta 1$ and angiotensin networking in cardiac remodelling. Cardiovasc. Res. 63, 423-432. doi: 10.1016/j.cardiores.2004.04.030

Roy, S., Khanna, S., Hussain, S. R., Biswas, S., Azad, A., Rink, C., et al. (2009). MicroRNA expression in response to murine myocardial infarction: miR-21 regulates fibroblast metalloprotease-2 via phosphatase and tensin homologue. Cardiovasc. Res. 82, 21-29. doi: 10.1093/cvr/cvp015

Samuel, C. S., Lekgabe, E. D., and Mookerjee, I. (2007). The effects of relaxin on extracellular matrix remodeling in health and fibrotic disease. Adv. Exp. Med. Biol. 612, 8-103. doi: 10.1007/978-0-387-74672-2_7

Sanna, M. G., Liao, J., Jo, E., Alfonso, C., Ahn, M. Y., Peterson, M. S., et al. (2004). Sphingosine 1-phosphate (S1P) receptor subtypes S1P1 and S1P3, respectively, regulate lymphocyte recirculation and heart rate. J. Biol. Chem. 279, 13839-13848. doi: 10.1074/jbc.M311743200 
Sanna, M. G., Wang, S. K., Gonzalez-Cabrera, P. J., Don, A., Marsolais, D., Matheu, M. P., et al. (2006). Enhancement of capillary leakage and restoration of lymphocyte egress by a chiral S1P1 antagonist in vivo. Nat. Chem. Biol. 2, 434-441. doi: 10.1038/nchembio804

Santos-Gallego, C. G., Vahl, T. P., Goliasch, G., Picatoste, B., Arias, T., Ishikawa, K., et al. (2016). Sphingosine-1-phosphate receptor agonist fingolimod increases myocardial salvage, and decreases adverse postinfarction left ventricular remodeling in a porcine model of ischemia/reperfusion. Circulation 133, 954-966. doi: 10.1161/CIRCULATIONAHA.115.012427

Satsu, H., Schaeffer, M. T., Guerrero, M., Saldana, A., Eberhart, C., Hodder, P., et al. (2013). A sphingosine 1-phosphate receptor 2 selective allosteric agonist. Bioorg. Med. Chem. 21, 5373-5382. doi: 10.1016/j.bmc.2013.06.012

Schulze, T., Golfier, S., Tabeling, C., Räbel, K., Gräler, M. H., Witzenrath, et al. (2011). Sphingosine-1-phospate receptor 4 (S1P4) deficiency profoundly affects dendritic cell function and TH17-cell differentiation in a murine model. FASEB J. 25, 4024-4036. doi: 10.1096/fj.10-179028

Schwalm, S., Pfeilschifter, J., and Huwiler, A. (2013). Sphingosine-1-phosphate: a Janus-faced mediator of fibrotic diseases. Biochim. Biophys. Acta 1831, 239-250. doi: 10.1016/j.bbalip.2012.07.022

Schwalm, S., Timcheva, T. M., Filipenko, I., Ebadi, M., Hofmann, L. P., Zangemeister-Wittke, U., et al. (2015). Sphingosine kinase 2 deficiency increases proliferation and migration of renal mouse mesangial cells and fibroblasts. J. Biol. Chem. 396, 813-825. doi: 10.1515/hsz-2014-0289

Shea, B. S., Brooks, S. F., Fontaine, B. A., Chun, J., Luster, A. D., and Tager, A. M. (2010). Prolonged exposure to sphingosine 1-phosphate receptor-1 agonists exacerbates vascular leak, fibrosis, and mortality after lung injury. Am. J. Respir. Cell. Mol. Biol. 43, 662-673. doi: 10.1165/rcmb.2009-0345OC

Sobel, K., Menyhart, K., Killer, N., Renault, B., Bauer, Y., Studer, R., et al. (2013). Sphingosine 1-phosphate (S1P) receptor agonists mediate pro-fibrotic responses in normal human lung fibroblasts via S1P2 and S1P3 receptors and smad-independent signaling. J. Biol. Chem. 288, 14839-14851. doi: 10.1074/jbc. M112.426726

Spinale, F. G. (2007). Myocardial matrix remodeling and the matrix metalloproteinases: influence on cardiac form and function. Physiol. Rev. 87, 1285-1342. doi: 10.1152/physrev.00012.2007

Spinale, F. G., Janicki, J. S., and Zile, M. R. (2013). Membrane-associated matrix proteolysis and heart failure. Circ. Res. 112, 195-208. doi: 10.1161/ CIRCRESAHA.112.266882

Sugahara, K., Maeda, Y., Shimano, K., Mogami, A., Kataoka, H., Ogawa, K., et al. (2017). Amiselimod, a novel sphingosine 1-phosphate receptor-1 modulator, has potent therapeutic efficacy for autoimmune diseases, with low bradycardia risk. Br. J. Pharmacol. 174, 15-27. doi: 10.1111/bph.13641

Suzuki, M., Cao, K., Kato, S., Komizu, Y., Mizutani, N., Tanaka, K., et al. (2016). Targeting ceramide synthase 6 dependent metastasis-prone phenotype in lung cancer cells. J. Clin. Invest. 126, 254-265. doi: 10.1172/JCI79775

Takahashi, M., Shimizu, H., Murakami, T., Enosawa, S., Suzuki, C., Takeno, Y., et al. (2005). A novel immunomodulator KRP-203 combined with cyclosporine prolonged graft survival and abrogated transplant vasculopathy in rat heart allografts. Transplant. Proc. 37, 143-145. doi: 10.1016/j.transproceed.2004. 12.107

Takuwa, N., Ohkura, S., Takashima, S., Ohtani, K., Okamoto, Y., Tanaka, T., et al. (2010). S1P3-mediated cardiac fibrosis in sphingosine kinase 1 transgenic mice involves reactive oxygen species. Cardiovasc. Res. 85, 484-493. doi: 10.1093/cvr/ cvp312

Takuwa, Y. (2002). Subtype-specific differential regulation of Rho family G proteins and cell migration by the Edg family, sphingosine-1-phosphate receptors. Biochim. Biophys. Acta 1582, 112-120. doi: 10.1016/S1388-1981(02)00145-2

Takuwa, Y., Ikeda, H., Okamoto, Y., Takuwa, N., and Yoshioka, K. (2013). Sphingosine-1-phosphate as a mediator involved in development of fibrotic diseases. Biochim. Biophys. Acta 1831, 185-192. doi: 10.1016/j.bbalip.2012. 06.008

Takuwa, Y., Okamoto, Y., Yoshioka, K., and Takuwa, N. (2008). Sphingosine1-phosphate signaling and biological activities in the cardiovascular system. Biochim. Biophys. Acta 1781, 483-488. doi: 10.1016/j.bbalip.2008.04.00

Tao, R., Zhang, J., Vessey, D. A., Honbo, N., and Karliner, J. S. (2007). Deletion of the sphingosine kinase-1 gene influences cell fate during hypoxia and glucose deprivation in adult mouse cardiomyocytes. Cardiovasc. Res. 74, 56-63. doi: 10.1016/j.cardiores.2007.01.015
Theilmeier, G., Schmidt, C., Herrmann, J., Keul, P., Schäfers, M., Herrgott, I., et al. (2006). High-density lipoproteins and their constituent, sphingosine1-phosphate, directly protect the heart against ischemia/reperfusion injury in vivo via the S1P3 lysophospholipid receptor. Circulation 114, 1403-1409. doi: 10.1161/CIRCULATIONAHA.105.607135

Thudichum, J. L. W. (1884). A Treatise on the Chemical Constitution of Brain. London: Bailliere, Tindall and Cox, 338.

Thum, T., Gross, C., Fiedler, J., Fischer, T., Kissler, S., Bussen, M., et al. (2008). MicroRNA-21 contributes to myocardial disease by stimulating MAP kinase signaling in fibroblasts. Nature 456, 980-984. doi: 10.1038/nature07511

Tijsen, A. J., van der Made, I., van den Hoogenhof, M. M., Wijnen, W. J., van Deel, E. D., de Groot, N. E., et al. (2014). The microRNA-15 family inhibits the TGF $\beta$-pathway in the heart. Cardiovasc. Res. 104, 61-71. doi: 10.1093/cvr/ cvu184

Tölle, M., Klöckl, L., Wiedon, A., Zidek, W., van der Giet, M., and Schuchardt, M. (2016). Regulation of endothelial nitric oxide synthase activation in endothelial cells by S1P1 and S1P3. Biochem. Biophys. Res. Commun. 476, 627-634. doi: 10.1016/j.bbrc.2016.06.009

Tomasek, J. J., Gabbiani, G., Hinz, B., Chaponnier, C., and Brown, R. A. (2002). Myofibroblasts and mechano-regulation of connective tissue remodelling. Nat. Rev. Mol. Cell. Biol. 3, 349-363. doi: 10.1038/nrm809

Tsukada, Y. T., Sanna, M. G., Rosen, H., and Gottlieb, R. A. (2007). S1P1-selective agonist SEW2871 exacerbates reperfusion arrhythmias. J. Cardiovasc. Pharmacol. 50, 660-669. doi: 10.1016/j.bbalip.2015.01.00

Tsuruda, T., Costello-Boerrigter, L. C., and Burnett, J. C. Jr. (2004). Matrix metalloproteinases: pathways of induction by bioactive molecules. Heart Fail. Rev. 9, 53-61. doi: 10.1023/B:HREV.0000011394.34355.bb

Tyagi, S. C., Ratajska, A., and Weber, K. T. (1993). Myocardial matrix metalloproteinase(s): localization and activation. Mol. Cell. Biochem. 126, 49-59.

Vachal, P., Toth, L. M., Hale, J. J., Yan, L., Mills, S. G., Chrebet, G. L., et al. (2006). Highly selective and potent agonists of sphingosine-1-phosphate 1 (S1P1) receptor. Bioorg. Med. Chem. Lett. 16, 3684-3687. doi: 10.1016/j.bmcl. 2006.04.064

Valentine, W. J., Kiss, G. N., Liu, J. E. S., Gotoh, M., Murakami-Murofushi, K., Pham, T. C., et al. (2010). (S)-FTY720-vinylphosphonate, an analogue of the immunosuppressive agent FTY720, is a pan-antagonist of sphingosine 1-phosphate GPCR signaling and inhibits autotaxin activity. Cell. Signal. 22, 1543-1553. doi: 10.1016/j.cellsig.2010.05.023

van den Borne, S. W., Diez, J., Blankesteijn, W. M., Verjans, J., Hofstra, L., and Narula, J. (2010). Remodeling after infarction: the role of myofibroblasts. Nat. Rev. Cardiol. 7, 30-37. doi: 10.1038/nrcardio.2009.199

van der Westhuizen, E. T., Halls, M. L., Samuel, C. S., Bathgate, R. A., Unemori, E. N., Sutton, S. W., et al. (2008). Relaxin family peptide receptors-from orphans to therapeutic targets. Drug Discov. Today 13, 640-651. doi: 10.1016/j. drudis.2008.04.002

van Rooij, E., Sutherland, L. B., Thatcher, J. E., DiMaio, J. M., Naseem, R. H., Marshall, W. S., et al. (2008). Dysregulation of microRNAs after myocardial infarction reveals a role of miR-29 in cardiac fibrosis. Proc. Natl. Acad. Sci. U.S.A. 105, 13027-13032. doi: 10.1073/pnas.0805038105

Vanhoutte, D., and Heymans, S. (2010). TIMPs and cardiac remodeling: 'embracing the MMP-independent-side of the family'. J. Mol. Cell. Cardiol. 48, 445-453. doi: 10.1016/j.yjmcc.2009.09.013

Vessey, D. A., Li, L., Honbo, N., and Karliner, J. S. (2009). Sphingosine 1-phosphate is an important endogenous cardioprotectant released by ischemic pre- and postconditioning. Am. J. Physiol. Heart Circ. Physiol. 297, H1429-H1435. doi: 10.1152/ajpheart.00358.2009

Vessey, D. A., Li, L., Jin, Z. Q., Kelley, M., Honbo, N., Zhang, J., et al. (2011). A sphingosine kinase form 2 knockout sensitizes mouse myocardium to ischemia/reoxygenation injury and diminishes responsiveness to ischemic preconditioning. Oxid. Med. Cell. Longev. 2011:961059. doi: 10.1155/2011/ 961059

Wamhoff, B. R., Lynch, K. R., Macdonald, T. L., and Owens, G. K. (2008). Sphingosine-1-phosphate receptor subtypes differentially regulate smooth muscle cell phenotype. Arterioscler. Thromb. Vasc. Biol. 28, 1454-1461. doi: 10.1161/ATVBAHA.107.159392

Wang, J., Wang, Y., Han, J., Li, Y., Xie, C., Xie, L., et al. (2015). Integrated analysis of microRNA and mRNA expression profiles in the left atrium of patients with 
nonvalvular paroxysmal atrial fibrillation: role of miR-146b-5p in atrial fibrosis. Heart Rhythm. 12, 1018-1026. doi: 10.1016/j.hrthm.2015.01.026

Wang, Q., Navitskaya, S., Chakravarthy, H., Huang, C., Kady, N., Lydic, T. A., et al. (2016). Dual anti-inflammatory and anti-angiogenic action of miR-15a in diabetic retinopathy. EBioMedicine 11, 138-150. doi: 10.1016/j.ebiom.2016. 08.013

Wei, C., Kim, I. K., Kumar, S., Jayasinghe, S., Hong, N., Castoldi, G., et al. (2013). NF-kappaB mediated miR-26a regulation in cardiac fibrosis. J. Cell. Physiol. 228, 1433-1442. doi: 10.1002/jcp.24296

Wijnen, W. J., Pinto, Y. M., and Creemers, E. E. (2013). The therapeutic potential of miRNAs in cardiac fibrosis: where do we stand? J. Cardiovasc. Trans. Res. 6, 899-908. doi: 10.1007/s12265-013-9483-y

Wynn, T. A. (2008). Cellular and molecular mechanisms of fibrosis. J. Pathol. 214, 199-210. doi: 10.1002/path.2277

Wynn, T. A., and Ramalingam, T. R. (2012). Mechanisms of fibrosis: therapeutic translation for fibrotic disease. Nat. Med. 18, 1028-1040. doi: 10.1038/nm. 2807

Xia, P., Wang, L., Moretti, P. A., Albanese, N., Chai, F., Pitson, S. M., et al. (2002). Sphingosine kinase interacts with TRAF2 and dissects tumor necrosis factor- $\alpha$ signaling. J. Biol. Chem. 277, 7996-8003. doi: 10.1074/jbc.M11142 3200

Xiao, H. Y., Watterson, S. H., Langevine, C. M., Srivastava, A. S., Ko, S. S., Zhang, Y., et al. (2016). Identification of tricyclic agonists of sphingosine1-phosphate receptor 1 (S1P1) employing ligand-based drug design. J. Med. Chem. 59, 9837-9854. doi: 10.1021/acs.jmedchem.6b01099

Xin, C., Ren, S., Eberhardt, W., Pfeilschifter, J., and Huwiler, A. (2006). The immunomodulator FTY720 and its phosphorylated derivative activate the Smad signalling cascade and upregulate connective tissue growth factor and collagen type IV expression in renal mesangial cells. Br. J. Pharmacol. 147, 164-174. doi: 10.1038/sj.bjp.0706452

Xin, C., Ren, S., Kleuser, B., Shabahang, S., Eberhardt, W., Radeke, H., et al. (2004). Sphingosine 1-phosphate cross-activates the Smad signaling cascade and mimics transforming growth factor-beta-induced cell responses. J. Biol. Chem. 279, 35255-35262. doi: 10.1074/jbc.M312091200

Yamanaka, M., Shegogue, D., Pei, H., Bu, S., Bielawska, A., Bielawski, J., et al. (2004). Sphingosine kinase 1 (SPHK1) is induced by transforming growth factor- $\beta$ and mediates TIMP-1 up-regulation. J. Biol. Chem. 279, 53994-54001. doi: 10.1074/jbc.M410144200

Yeh, C. C., Li, H., Malhotra, D., Huang, M. C., Zhu, B. Q., Goetzl, E. J., et al. (2009). Sphingolipid signaling and treatment during remodeling of the uninfarcted ventricular wall after myocardial infarction. Am. J. Physiol. Heart Circ. Physiol. 296, H1193-H1199. doi: 10.1152/ajpheart.01032.2008
Yu, H., Duan, P., Zhu, H., and Rao, D. (2017). miR-613 inhibits bladder cancer proliferation and migration through targeting SphK1. Am. J. Transl. Res. 9, 1213-1221.

Yung, B. S., Brand, C. S., Xiang, S. Y., Gray, C. B., Means, C. K., Rosen, H., et al. (2017). Selective coupling of the S1P3 receptor subtype to S1P-mediated RhoA activation and cardioprotection. J. Mol. Cell. Cardiol. 103, 1-10. doi: 10.1016/j.yjmcc.2016.12.008

Zhang, J., Honbo, N., Goetzl, E. J., Chatterjee, K., Karliner, J. S., and Gray, M. O. (2007). Signals from type 1 Sphingosine 1-phosphate receptors enhance adult mouse cardiac myocyte survival during hypoxia. Am. J. Physiol. 293, H3150-H3158. doi: 10.1152/ajpheart.00587.2006

Zhang, Y., Huang, X. R., Wei, L. H., Chung, A. C., Yu, C. M., and Lan, H. Y. (2014). miR-29b as a therapeutic agent for angiotensin II-induced cardiac fibrosis by targeting TGF-beta/Smad3 signaling. Mol. Ther. 22, 974-985. doi: 10.1038/mt. 2014.25

Zhang, Z. Y., Zhang, Z., Zug, C., Nuesslein-Hildesheim, B., Leppert, D., Schluesener, H. J., et al. (2009). AUY954, a selective S1P(1) modulator, prevents experimental autoimmune neuritis. J. Neuroimmunol. 216, 59-65. doi: 10.1016/ j.jneuroim.2009.09.010

Zhao, Y., Ling, Z., Hao, Y., Pang, X., Han, X., Califano, J. A., et al. (2017). MiR-124 acts as a tumor suppressor by inhibiting the expression of sphingosine kinase 1 and its downstream signaling in head and neck squamous cell carcinoma. Oncotarget 8, 25005-25020. doi: 10.18632/oncotarget.15334

Zou, M., Wang, F., Gao, R., Wu, J., Ou, Y., Chen, X., et al. (2016). Autophagy inhibition of hsa-miR-19a-3p/19b-3p by targeting TGFbeta, R II during TGFbetal-induced fibrogenesis in human cardiac fibroblasts. Sci. Rep. 6:24747. doi: 10.1038/srep24747

Zu Heringdorf, D. M., Ihlefeld, K., and Pfeilschifter, J. (2013). Pharmacology of the sphingosine-1-phosphate signaling system. Handb. Exp. Pharmacol. 215, 239-253. doi: 10.1007/978-3-7091-1368-4_13

Conflict of Interest Statement: The authors declare that the research was conducted in the absence of any commercial or financial relationships that could be construed as a potential conflict of interest.

Copyright (c) 2017 Vestri, Pierucci, Frati, Monaco and Meacci. This is an openaccess article distributed under the terms of the Creative Commons Attribution License (CC BY). The use, distribution or reproduction in other forums is permitted, provided the original author(s) or licensor are credited and that the original publication in this journal is cited, in accordance with accepted academic practice. No use, distribution or reproduction is permitted which does not comply with these terms. 